\title{
INFLUENCE OF SEASONALITY AND POLLUTION ON THE HEMATOLOGICAL PARAMETERS OF THE ESTUARINE FISH Centropomus parallelus
}

\author{
Robson Seriani ${ }^{1}$, Denis Moledo de Souza Abessa ${ }^{1}$, Camilo D. S. Pereira ${ }^{2}$, Aline A. Kirschbaum ${ }^{2}$, Andrea \\ Assunção ${ }^{2}$ and Maria José T. Ranzani-Paiva ${ }^{3}$ \\ ${ }^{1}$ Universidade Estadual Paulista Júlio de Mesquita Filho - UNESP \\ Campus Experimental do Litoral Paulista \\ (Praça Infante Dom Henrique, s/n, 11330-900 São Vicente, SP, Brasil) \\ ${ }^{2}$ Universidade Santa Cecília \\ (Rua Oswaldo Cruz, 277, 11045-907 Santos, SP, Brasil) \\ ${ }^{3}$ Instituto de Pesca - SP - IP/SAA-APTA \\ Laboratório de Patologia de Organismos Aquáticos \\ (Av, Francisco Matarazzo, 455, 05001-000 São Paulo, SP, Brasil) \\ *Corresponding author: robsonseriani@yahoo.com.br
}

\begin{abstract}
A B S T R A C T
This study investigated the hematological parameters of the tropical estuarine fish Centropomus parallelus and their use as a non-destructive biomarker for aquatic pollution. Individuals were collected, in summer and winter, at two estuaries, Cananéia (CAN) and São Vicente (SVE), and blood was extracted by caudal puncture. The evaluated parameters were hematocrit $(\mathrm{Ht})$, red blood cells (RBC), Mean Corpuscular Volume (MCV), and the leukocyte (WBC) and thrombocyte counts. Fishes from CAN showed higher values of absolute number of thrombocytes in the summer. The fishes from SVE presented lower values of $\mathrm{Ht}$ and $\mathrm{MCV}$ in winter. Comparing the hematological parameters of fishes from these two sites, $\mathrm{Ht}, \mathrm{MCV}, \mathrm{WBC}$ and $\mathrm{RBC}$ were higher in fishes from SVE in the summer, whereas during the winter, Ht and thrombocytes were higher in animals from SVE. The results allow attributing the changes in the blood of fishes to seasonality and the presence of contaminants.
\end{abstract}

\section{RESUMO}

No presente estudo, foram utilizados parâmetros hematológicos do peixe tropical estuarino Centropomus parallelus como biomarcador não destrutivo. Os peixes foram coletados, no verão e no inverno, em dois estuários: Cananéia (CAN) e São Vicente (SVE). Foram analisados: hematócrito (Ht), contagem de eritrócitos (RBC), volume corpuscular médio (VCM), leucograma (WBC) e trombograma. Os peixes de ambos locais apresentaram variações no quadro hematológico devido à sazonalidade e aos níveis de degradação ambiental. Os peixes de Cananéia apresentaram aumento no número absoluto de trombócitos no verão, enquanto aqueles coletados em São Vicente apresentaram hematócrito (Ht) e Volume Corpuscular Médio (MCV) menor no inverno. Comparando o quadro hematológico dos peixes dos dois estuários, observamos maiores valores de hematócrito (Ht), Volume Corpuscular Médio (MCV), leucócitos (WBC), e número de eritrócitos (RBC) nos peixes de São Vicente no verão, enquanto no inverno, Ht e trombócitos foram também maiores nos peixes desse local. Os resultados sugerem que as alterações observadas no quadro hematológico se deveram à qualidade ambiental dos estuários e à sazonalidade.

Descriptors: Hematology, Centropomus parallelus, Estuary, Contamination. Descritores: Hematologia, Centropomus parallelus, Estuário, Contaminação.

\section{INTRODUCTION}

Estuaries are of great ecological and economic importance, providing humans with essential products and services. However, due to their geographical characteristics, estuaries have been severely impacted, not only by direct destruction, to make room for anthropic structures such as cities, industrial facilities, aquaculture farms, ports and harbors, marinas and others, but also because they are threatened by pollution, resulting in a variety of biological effects, from biochemical and genetic 
disturbance to ecological imbalance, which could threaten the ecological processes and consequently the economic exploitation of biological resources, with negative effects on the economy. Aquatic pollution may also affect human health by leading to the consumption of contaminated seafood (CLARK 1997; VAN DER OOST et al., 2003; SOUSA et al., 2007; ABESSA et al., 2008, PEREIRA, et al., 2012).

Different biomarkers in fishes, especially biochemical and histological alterations as well as genotoxic effects, have been incorporated into environmental quality evaluations and ecological risk assessments (VOS et al., 1989; WEEKS et al., 1992; WALKER et al., 1996, VAN DER OOST et al., 2003; KIRSCHBAUM et al., 2009), as additional Lines Of Evidence (LOEs), and have therefore become an important part of such studies.

Fish blood parameters can be considered promising new candidates for biomarkers for environmental monitoring, as they constitute a nondestructive and simple method (FRANÇA et al., 2007; SERIANI \& RANZANI-PAIVA, 2012). Blood samples can regularly be obtained from test organisms, thus allowing the use of non-destructive approaches to the assessment of physiological alterations in pollutant effects driven studies. Hematological responses have been considered a reliable health status descriptor of organisms. Moreover, the blood incorporates several levels of organization, such as physiology, histology, cytology and hormonal regulation; it must be related to both endogenous and environmental factors that induce stress, including contaminants (BEYER, 1996; SERIANI \& RANZANI-PAIVA, 2012). The literature shows that fishes exposed to metals, pesticides and effluents present hematological changes, both in laboratory and under field conditions (RANZANIPAIVA et al., 1997; FRANÇA et al., 2007; SERIANI et al., RANZANI-PAIVA, 2012). In addition, there is a need to expand knowledge on the hematology of different species, especially those from marine and estuarine environments, which includes the comprehension of how they respond to contaminants and other stressors. According to Ranzani-Paiva; Silva-Souza (2004), it is necessary to determine the normal standards for the blood of healthy specimens of each fish species, as well as to understand how the blood responds to environmental contamination.

The fat snook, Centropomus parallelus, is widely distributed in coastal marine and estuarine environments from southern Florida to southeastern Brazil (RIVAS, 1986) and represents an important food resource for the local populations as well as an important economic resource, especially because its meat is very tasty and fetches high market values. Moreover, as a predator which feeds on small fishes and benthic invertebrates, this species occupies an important position in the aquatic food web, and has potential for cultivation in captivity. On the other hand, it is vulnerable to the phenomena of contaminants bioconcentration and biomagnification due to its feeding habits.

This research seeks to assess the influence of seasonal patterns and exposure to contaminants on the hematological characteristics of $C$. parallelus collected in subtropical estuaries with different degrees of contamination.

Two estuaries situated in São Paulo State, Brazil, were considered for this investigation: Cananéia Estuary (CAN) and São Vicente Estuary (SVE) (Fig. 1). São Vicente Estuary (SVE) is a part of the Santos Estuarine System, which is considered highly impacted by anthropic interventions and pollution (BOLDRINI; PEREIRA, 1987; MEDEIROS; BÍCEGO, 2004; SIQUEIRA et al., 2005; BÍCEGO et al., 2006; CESAR et al., 2006; HORTELLANI, et al., 2008; MARTINS et al., 2008; KIRSCHBAUM et al., 2009, SERIANI, et al., 2010). The SVE receives mainly domestic pollution from diffuse sources, specially sewage, stormwater and urban drainage, but contamination from domestic and industrial landfills is also considerable (LAMPARELLI et al., 2001). Recent data on the SVE have shown that the discharge of contaminants from land-based sources has increased the concentration of several substances, many of which are already present in concentrations high enough to cause biological risks (LAMPARELLI et al., 2001; ABESSA et al., 2008; KIRSCHBAUM et al., 2009; SERIANI et al., 2010, PEREIRA, et al.,2012). On the other hand, the Cananéia Estuary (CAN) presents lower levels of contaminants. According to Lamparelli et al. (2006; 2007) and Kirschbaum et al. (2009), CAN is a relatively unpolluted estuary which may be taken as a reference area.

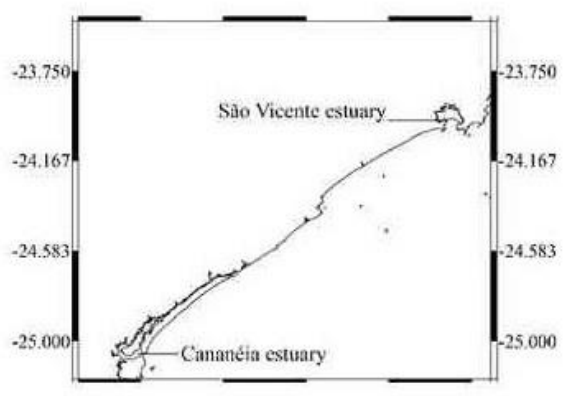

Fig. 1. Sao Vicente $\left(23^{\circ} \mathrm{S}-46^{\circ} \mathrm{W}\right)$ and Cananéia $\left(25^{\circ} \mathrm{S}-48^{\circ} \mathrm{W}\right.$ ) estuaries (adapted from KIRSCHBAUM et al., 2009).

Each study site (SVE and CAN) was sampled twice, with sampling campaigns in winter and summer. The field sampling consisted of the collection of 
ten $C$. parallelus individuals $(165.02 \pm 35.01 \mathrm{~g}$ and $23.02 \pm 5.01 \mathrm{~cm})$ at each site. At each field sampling, the water temperature was measured in situ using mercury thermometers, and three samples of water were taken for the determination of $\mathrm{pH}$ and salinity in the laboratory.

The captured fishes were then transported to the laboratory in accordance with Kubitza (1997) and acclimatized during 60 minutes. After they had been anesthetized with clove oil (SERIANI, et al., 2011), the blood was drawn by caudal puncture, using heparin-treated syringes. Blood aliquots were separated for the following measurements: hematocrit (Ht), by the microhematocrit method, and red blood cells (RBC) in a Neubauer chamber, using $0.7 \% \mathrm{NaCl}$ as diluent. The Mean Corpuscular Volume (MCV) was determined in accordance with Wintrobe (1934). For each collected fish, two blood smear slides were prepared and stained with May-Grünwald-Giemsa dye (ROSENFELD, 1947). Each slide was used to count total leukocytes (WBC) and thrombocytes (TRB) in 2000 cells, by the indirect method, in accordance with Hrubec; Smith (1998).

The Kolmogorov-Smirnov normality test was performed. Thrombocyte data were not distributed normally and were transformed using $\log 10$. Afterwards, the results obtained for the two sites were compared with the General Linear Model (GLM) Multivariate for one dependent variable by two factors, both locations and periods being considered as factors; post-hoc comparisons used Tukey's test to identify divergent groups. The GLM Multivariate procedure provides regression analysis and analysis of variance for multiple dependent variables by one or more factor variables or covariates, allowing for the test of null hypotheses regarding the effects of factor variables on the means of various groupings of a joint distribution of dependent variables and also for the investigation of interactions between factors as well as the effects of individual factors. The statistical package used was SPSS version 17, SPSS ® Inc., Chicago, II, and the statistical level of significance was set at $5 \%$.

The physical-chemical parameters of the water samples collected in both estuaries are given in Table 1. Water temperatures varied according to the seasonal conditions at both estuaries, with higher values in the summertime. Salinities were markedly lower at $\mathrm{CAN}$, on both campaigns, whereas $\mathrm{pH}$ values were lower in SVE waters.

The results obtained at SVE and CAN in the winter and summer campaigns are displayed in Table 2. Fishes from SVE presented significantly higher values of $\mathrm{Ht}, \mathrm{MCV}$ and TRB in summer than in winter, whereas those from CAN presented significantly higher values of thrombocytes during the summer. The data obtained for each estuary were also compared. In winter, $\mathrm{Ht}$ and TRB values were significantly higher in fishes from SVE while in summer $\mathrm{Ht}, \mathrm{RBC}, \mathrm{MCV}$ and $\mathrm{WBC}$ were higher in SVE animals.

Table 1. Physical-chemical parameters of waters from Cananéia and São Vicente Estuaries during Winter and Summer.

\begin{tabular}{llll}
\hline \hline Estuary & $\begin{array}{l}\text { Physical- } \\
\text { chemical } \\
\text { parameters }\end{array}$ & \multicolumn{1}{c}{ Winter } & Summer \\
\hline Cananéia & $\mathbf{p H}$ & $7.3 \pm 0.3$ & $8.0 \pm 0.6$ \\
& $\mathbf{T}^{\mathbf{0}} \mathbf{C}$ & $22.0 \pm 1.0$ & $32.0 \pm 3.0$ \\
& Salinity & $3.1 \pm 0.2$ & $6.1 \pm 0.6$ \\
& $\mathbf{p H}$ & $7.0 \pm 0.1$ & $6.9 \pm 0.4$ \\
São & $\mathbf{T}^{\mathbf{0}} \mathbf{C}$ & $20.5 \pm 0.5$ & $29.8 \pm 0.2$ \\
Vicente & Salinity & $27.1 \pm 1.1$ & $27.1 \pm 0.5$ \\
& & & \\
\hline
\end{tabular}

Table 2. Hematological parameters of $C$. parallelus from SV and CAN Estuary in winter and summer seasons.

\begin{tabular}{|c|c|c|c|c|c|c|c|c|c|c|c|c|}
\hline \multirow[t]{3}{*}{ Parameters } & \multicolumn{5}{|c|}{ Winter } & \multicolumn{7}{|c|}{ Summer } \\
\hline & \multicolumn{3}{|c|}{ São Vicente (n=11) } & \multicolumn{3}{|c|}{ Cananéia $(n=10)$} & \multicolumn{3}{|c|}{ São Vicente (n=9) } & \multicolumn{3}{|c|}{ Cananéia (n=10) } \\
\hline & Mean & & SD & Mean & & SD & Mean & & SD & Mean & & SD \\
\hline Hematocrit (\%) & 36.00 & \pm & 5.10 & 29.55 & \pm & $3.4^{\mathrm{b}}$ & 45.67 & \pm & $4.80^{\mathrm{a}}$ & 32.10 & \pm & $7.85^{\mathbf{a}, \mathrm{b}}$ \\
\hline $\operatorname{RBC}\left(10^{4} / \mu \mathrm{L}\right)$ & 272.36 & \pm & 34.38 & 231.00 & \pm & $114.03^{\mathrm{c}}$ & 284.89 & \pm & 31.48 & 240.00 & \pm & $38.65^{\mathrm{c}}$ \\
\hline $\operatorname{MCV}(f l)$ & 134.22 & \pm & 26.28 & 127.71 & \pm & 39.26 & 161.31 & \pm & 18.00 & 132.63 & \pm & 20.12 \\
\hline WBC $(\mu \mathrm{L})$ & 4.63 & \pm & 3.11 & 2.68 & \pm & $1.57^{\mathrm{d}}$ & 8.11 & \pm & 6.19 & 3.29 & \pm & $2.19^{d}$ \\
\hline Thrombocytes - Log10 (\%) & 4.70 & \pm & 0.27 & 4.13 & \pm & 0.40 & 4.84 & \pm & $0.51^{\mathrm{a}}$ & 4.95 & \pm & $0.58^{\mathrm{a}}$ \\
\hline
\end{tabular}

${ }^{\mathrm{a}}$ summer $\neq$ winter $(\mathrm{p}<0.01) ;{ }^{\mathrm{b}} \mathrm{CAN} \neq \mathrm{SV}(\mathrm{p}<0.001) ;{ }^{\mathrm{c}} \mathrm{CAN} \neq \mathrm{SV}(\mathrm{p}<0.05) ;{ }^{\mathrm{d}} \mathrm{CAN} \neq \mathrm{SV}(\mathrm{p}<0.01)$;

Note: summer $=$ winter in $\mathrm{a}$. 
In winter, $\mathrm{Ht}$ and $\mathrm{MCV}$ values were lower in both CAN and SVE. It is recognized that the temperature can influence the metabolic activity of fish (SCHMIDT-NIELSEN, 2002). At lower temperatures, the fishes tend to reduce their metabolism (CLARKE; JOHNSTON, 1999) and consequently their oxygen consumption; under these conditions, the RBC production should be reduced, being reflected in the lower values of $\mathrm{Ht}$ and $\mathrm{MCV}$ during this season. In summer, the significant increase of MCV in fishes from SVE must reflect the release of immature cells into the blood stream, because at this stage the cells are bigger but contain less hemoglobin.

Further, the number of thrombocytes in individuals from CAN presented a seasonal variation, with higher values in summer, in a similar way to that observed for Cirrhinus mrigala (RAIZADA; SING, 1981). Although such variation may be due to seasonality, as this cell type is subject to seasonal natural influences, further studies should be conducted to better understand these variations in $C$. parallelus.

Our results showed higher $\mathrm{Ht}$ values in $C$. parallelus from SVE both in winter and summer. Many authors have reported the increase of Ht levels in different fish species exposed to contaminants. This response was observed in Pimelodus maculatus and Tilapia zilli exposed to sewage (JERONIMO et al., 2009; SAAD et al., 1973), in Pagothenia borchgrevinski exposed to hydrocarbons (DAVISON et al., 1992), in O. mossambicus exposed to copper (NUSSEY et al., 1995), in Rhamdia hilarii exposed to herbicide and in Hoplias malabaricus exposed to methyl mercury (OLIVEIRA RIBEIRO et al., 2006). As the increases in Ht levels occur together with higher RBC values, such variations may have a variety of causes which were not evaluated in this study but which require further investigation: i) the increases in Ht levels could be a response to summer hypoxia (due to enhanced microbial activity at higher temperatures) or to lower levels of dissolved oxygen in more saline waters; ii) they could be attributed to an attempt to optimize the process of detoxification of contaminants inducing the production of erythrocytes and consequently of hematocrit; iii) they could be a result of the stimulation by cell hemolysis caused by pollutants; among other causes. More studies are required to elucidate the mechanisms involved in red blood cell production in fishes.

The total number of leukocytes (WBC) was higher in individuals from SVE, especially during the summer, suggesting the existence of leukocytosis in the animals from SVE or leucopenia in those from CAN. If leukocytosis in SVE fishes is assumed, such a result would contrast with those obtained by Vos et al. (1989) and Weeks et al. (1992), who described a suppression of the immune system in fish exposed to pollutants. Our study would suggest that the leukocytosis was directly related to environmental stress. This correlation has been reported for the freshwater fish Sarotherodon mossambicus exposed to sublethal concentrations of copper and endosulfan (SARAVANAN; HARIKRISHNAN, 1999), for Heteropneustes fossilis exposed to nickel (NANDA, 1997), for Channa punctata exposed to lead (HYMAVATHI; RAO, 2000), for Clarias batrachus exposed to mercuric chloride (JOSHI et al., 2002) and for Labeo rohita collected in the polluted Lakes of Bangalore, Karnataka, India (ZUTSHI et al., 2010). In this context, the increase in leukocytes in the blood of C. paralellus would be a result of direct stimulation for its defense against disease, in the presence of pollutants would be an immune reaction in the presence of pollutants.

The mechanisms involved in the production of leukocytes are closely related to the cortisol metabolism. Under environmental stress, there is a release of cortisol into the blood, and as a consequence the production and release of leukocytes are inhibited, resulting in a weakened immune system in fishes (WENDELAAR-BONGA, 1997; CHEN et al., 2002). So a lower number of WBC is to be expected in fishes from SVE. However, it is possible that other complex processes may be involved, thus allowing the increase of leukocytes in the fishes from SVE. On the other hand, if the possibility of leucopenia in CAN animals is considered, our results are in agreement with those reported by Vos et al., (1989) and Weeks et al., (1992). The presence of lead and pesticides in sediments from CAN, during summertime (MAHIQUES et al., 2009), brought by the Ribeira de Iguape River, would then be related to these responses.

The causal relationships between immunotoxic pollutants and fish diseases as well as the ecological significance of such effects in the field still remain unclear. It is possible that the immunological disruption caused by pollutants serves as a causal factor in the origin of fish diseases with multifactorial etiology, e.g. various skin diseases such as lymphocystis, papillomas, fin erosion, fin rot and skin ulcers. In certain situations, however, the opposite effect, i.e. protection of the fish against pathogens, may be observed after exposure to pollutants (MACFARLANE et al., 1986). However, in cases of sub-acute or chronic exposure, hematological parameters should decrease due to the depletion of the hematopoietic function. Kirschbaum et al. (2009) reported the presence of tumor and citogenotoxicy effects in $C$. parallelus from SVE and suggested that they could be due to environmental contamination with substances such as PAHs and PCBs, of carcinogenic, mutagenic and teratogenic potential.

It was observed, in view of the environmental degradation at SVE due to high levels 
of metals, detergents, hydrocarbons, PCBs and other pollutants (LAMPARELLI et al., 2001; HORTELLANI et al., 2008; CESAR et al., 2006; ABESSA et al., 2008, PEREIRA, et al., 2012), that fishes there presented higher values for most of the hematological parameters analyzed, especially in the summer, than did those from CAN. Thus these hematological alterations were probably related to the effects of pollutants present in the SVE, or to their combination with natural factors. Therefore, this study shows that the blood parameters of $C$. parallelus respond to seasonal variations, as observed in individuals from both SVE and CAN. In addition, hematological responses were significantly influenced by the respective collection sites, which corroborates the conclusion that pollution contributed to the effects observed in fat-snook.

Such assumptions are corroborated by the obtained data, since the difference of temperature between seasons was about $10^{\circ} \mathrm{C}$, with the considerable possibility of temperature variations' influencing hematological parameters, quite apart from the effects of environmental degradation. The influence of $\mathrm{pH}$ and salinity in the blood parameters found in this study is inconclusive, and probably such variables were not the main factors influencing the blood parameters, especially because the physicalchemical water conditions tend continuously to change in both estuaries (due to tidal influence and freshwater inputs thus in view of the estuarine hydrodynamics, it may be assumed that on the long term such variables have a similar influence on fishes at both sites (ABESSA et al., 2008; Harari et al., 2008; Seriani et al., 2006; 2008)

In brief, fish blood parameters can be considered good new candidate biomarkers for environmental monitoring in tropical estuaries, with the advantage of their depending on a non-lethal, inexpensive and simple method. Furthermore, this study shows that ecotoxicological studies employing the hematology of $C$. parallelus and other estuarine and marine fishes must take the influence of seasonality and natural factors into consideration.

\section{REFERENCES}

ABESSA, D. M. S.; CARR, R. S.; SOUSA, E. C. P. M.; RACHID, B. R. F.; ZARONI, L. P.; PINTO, Y. A.; GASPARRO, M. R.; BÍCEGO, M. C.; HORTELLANI, M. A.; SARKIS, J. E. S. Integrative ecotoxicological assessment of a complex tropical estuarine system. In: HOFER, T. N. (Ed.). Marine pollution: new research. Hauppauge: Nova Science; Lancaster: Gazelle, 2008. p. 1-36. (Science, Technology \& Business).

BEYER, J. Fish biomarkers in marine pollution monitoring: evaluation and validation in laboratory and field studies. Norway: University of Bergen, 1996. p123.
BÍCEGO, M.; TANIGUCHI, S.; YOGUI, G.; MONTONE, R.; SILVA, D.; LOURENCO, R.; MARTINS, C.; SASAKI, S.; PELLIZARI, V.; WEBER, R. Assessment of contamination by polychlorinated biphenyls and aliphatic and aromatic hydrocarbons in sediments of the Santos and São Vicente Estuary System, São Paulo, Brazil. Mar. Pollut. Bull., v. 52, p. 1804-1816, 2006.

BOLDRINI, C. V.; PEREIRA, D. N. Metais pesados na baía de Santos e estuários de Santos e São Vicente: bioacumulação. Ambiente, v. 1, n. 3, p. 118-127, 1987.

CESAR, A.; PEREIRA, C. D. S.; SANTOS, A. R.; ABESSA, D. M. S.; FERNANDEZ, N.; CHOUERI, R. B.; DELVALLS, T. A. Ecotoxicological assessment of sediments from the Santos and São Vicente estuarine system - Brazil. Braz. J. Oceanogr., v. 54, n. 1, p. 5563, 2006.

CLARK, R. B. Marine pollution. 4.ed. Oxford: New York: Oxford University Press, 1997. $161 \mathrm{p}$.

CLARKE, A.; JOHNSTON, N. M. Scaling of metabolic rate with body mass and temperature in teleost fish. J. Anim. Ecol., v. 68, n. 5, p.893-905, 1999.

CHEN, W. H.; SUN, L. T.; TSAI, C. L.; SONG, Y. L.; CHANG, C. F. Cold-stress induced the modulation of catecholamines, cortisol, immunoglobulin $\mathrm{M}$, and leukocyte phagocytosis in tilapia. Gen. Comp. Endocrinol., v. 126, n. 1, p. 90-100, 2002.

DAVISON, W.; FRANKLIN, C. E.; MCKENZIE, J. C.; DOUGAN, M. C. R. The effects of acute exposure to the water soluble fraction of fuel oil on survival and metabolic rate of an Antarctic fish Pagothenia borchgrevinki. Comp. Biochem. Physiol., v. 102C, p. 185-188, 1992.

FRANÇA, J. G.; RANZANI-PAIVA, M. J. T.; LOMBARDI, J. V.; CARVALHO, S.; SERIANI, R. Toxicidade crônica do cloreto de mercúrio $(\mathrm{HgCl} 2)$ associado ao selênio, através do estudo hematológico em tilápia Oreochromisniloticus. Bioikos, v. 21, p. 11-19, 2007.

HARARI, J.; FRANÇA, C. A. S.; CAMARGO, R. Climatology and hidrography of Santos Estuary. In: Neves, R.; Baretta, J.; Mateus, M. (Ed. ). Perspectives on integrated coastal zone management in South America. Lisboa: IST Press, 2008. p. 147-160.

HORTELlANI, M. A.; SARKIS, J. E. S.; ABESSA, D. M. S.; SOUSA, E. C. P. M. Avaliação da contaminação por elementos metálicos dos sedimentos do Estuário Santos São Vicente. Quím. Nova, v. 31, n. 1, p. 10-19, 2008.

HRUBEC, T. C.; SMITH, S. A. Hematology of fish. In: FELDMAN, B. F.; ZINKL, J. G.; JAIN, N. C.; SCHALM, O. W. Schalm's veterinary hematology. 5.ed. Philadelphia: London: Lippincott Williams \& Wilkins, 2000. p. 1120-1125.

HYMAVATHI, V.; RAO, L. M. Effect of sublethal concentration of lead on the haematology and the biochemical constituence of Channa punctata. Bull. Pure Appl. Sci., v. 19, p. 1-5, 2000.

JERONIMO, G.; MARTINS, M. L.; BACHMANN, F.; GREINER-GOULART, J. A.; SCHIMITT Jr., A. A.; GHIRALDELLI, L. Hematological parameters of Pimelodus maculatus (Osteichthyes: Pimelodidae) from polluted and non-polluted sites in the Itajaí-Açu river, Santa Catarina State, Brazil. Acta Sci., Biol. Sci., v. 31, n. 2, p. $179-183,2009$ 
JOSHI, P. K.; BOSE, M.; HARISH, D. Haematological changes in the blood of Clarias batrachus exposed to mercuric chloride. J. Ecotoxicol. Environ. Monit., v. 12, p. 119-122, 2002.

KIRSCHBAUM, A. A.; SERIANI, R.; ABESSA, D. M. S.; PEREIRA, C. D. S.; RANZANI-PAIVA, M. J. T. Cytogenotoxicity biomarkers in fat snook Centropomus parallelus from Cananéia and São Vicente estuaries, SP, Brazil. Genet. Mol. Biol., v. 32, n. 1, p. 151-154, 2009.

KUBITZA, F. Transporte de peixes vivos. Panorama Aqüicultura, v. 7, p. 44, 1997.

LAMPARELLI, M. C.; COSTA, M. P.; PRÓSPERI, V. A.; BEVILACQUA, J. E.; ARAÚJO, R. P. A.; EYSINK, G. G. J.; POMPÉIA, S. Sistema estuarino de Santos e São Vicente. São Paulo: Secretaria de Estado do Meio Ambiente, 2001. 183 p. In: CETESB. Água. Praias. Sistema estuarino de Santos e São Vicente. 2001 Relatório. Disponível em: http://www.cetesb.sp.gov.br/agua/praias/25-publicacoes/-relatorios. Acesso em: Acesso em: 11/12/2012

LAMPARELlI, M. C.; MOURA, D. O.; PINTO, K. C.; CAMOLEZ, A. C.; FORTIS, R. M.; CARDOSO, G. F.; SILVA, R. F. C.; PEREIRA, C. B. P. Relatório de qualidade das águas litorâneas no Estado de São Paulo 2005. São Paulo: CETESB, 2006. 254 p. (Série Relatórios). In: CETESB. Água. Praias. Publicações e Relatórios. Relatório de qualidade das águas litorâneas no Estado de São Paulo. 2005 - Relatório. Disponível em: $\quad$ http://www.cetesb.sp.gov.br/agua/praias/25publicacoes-/-relatorios. Acesso em: 11/12/2012

LAMPARELLI, M. C.; MOURA, D. O.; PINTO, K. C.; CAMOLEZ, A. C.; NERY, D.; FORTIS, R. M.; PEREIRA, C. B. P. Relatório de qualidade das águas litorâneas no Estado de São Paulo: balneabilidade das praias 2006. São Paulo: CETESB, 2007. 365 p. (Série Relatórios). In: CETESB. Água. Praias. Publicações e Relatórios. Relatório de qualidade das águas litorâneas no Estado de São Paulo. 2006 - Relatório. Disponível em: $\quad$ http://www.cetesb.sp.gov.br/agua/praias/25publicacoes-/-relatorios. Acesso em: Acesso em: $11 / 12 / 2012$

MACFARLANE, R. D.; BULLOCK, G. L.; MCLAUGHLIN, J. J. A. Effects of five metals on susceptibility of striped bass to Flexibacter columnaris. Trans. Am. Fish. Soc., v. 115, p. 227-231, 1986.

MAHIQUES, M. M.; BURONE, L.; FIGUEIRA, R. C. L.; LAVENERE-WANDERLEY, A. A.; CAPELLARI, B.; ROGACHESKI, C. E.; BARROSO, C. P.; SANTOS, L. A. S.; CORDERO, L. M. Anthropogenic influences in a lagoonal environment: A multiproxy approach at the Valo Grande mouth, Cananéia-Iguape system (SE Brazil). Braz. J. Oceanogr., v. 57, p. 325-337. 2009.

MARTINS, C. C.; FERREIRA, J. A.; TANIGUCHI, S.; MAHIQUES, M. M.; BÍCEGO, M. C.; MONTONE, R. C. Spatial distribution of sedimentary linear alkylbenzenes and faecal steroids of Santos Bay and adjoining continental shelf, SW Atlantic, Brazil: origin and fate of sewage contamination in the shallow coastal environment. Mar. Pollut. Bull., v. 56, p. 1359-1363, 2008.

MEDEIROS, P.; BICEGO, M. C. Investigation of natural and anthropogenic hydrocarbon inputs in sediments using geochemical markers. I. Santos, SP, Brazil. Mar. Pollut. Bull., v. 49, p. 761-769, 2004.

NANDA, P. Haematological changes in the common Indian catfish Heteropneustes fossilis under nickel stress. J. Ecobiol., v. 9, p. 243-246, 1997.

NUSSEY, G.; VAN VUREN, J. H. J.; DU-PREEZ, H. H. Effect of copper on the haematology and osmoregulation of the Mozambique tilápia, Oreochromis mossambicus (Cichlidade). Comp. Biochem. Physiol., Part C: Pharmacol., Toxicol. Endocrinol., v. 111, n. 3, p. 369380, 1995.

OLIVEIRA RIBEIRO, C. A.; FILIPAK, N. F.; MELA, M.; SILVA, P. H.; RANDIB, M. A. F.; RABITTO, I. S.; ALVES COSTA, J. R. M.; PELlETIER, E. Hematological findings in neotropical fish Hoplias malabaricus exposed to subchronic and dietary doses of methylmercury, inorganic lead, and tributyltin chloride. Environ. Res., v. 101, p. 74-80, 2006.

PEREIRA, C. D.; MARTÍN-DÍAZ, M. L.; CATHARINO, M. G.; CESAR, A.; CHOUERI, R. B.; TANIGUCHI, S.; ABESSA, D. M.; BÍCEGO, M. C.; VASCONCELLOS, M. B.; BAINY, A. C.; SOUSA, E. C. P. M.; DELVALLS, T. A. Chronic contamination assessment integrating biomarkers' responses in transplanted mussels-A seasonal monitoring. Environ. Toxicol., v. 27, n. 5, p. 257-267, 2012.

RAIZADA, M. N.; SING, C. P. Seazonal variations in the diferencial leucocyte count (DLC) of Cirrhinus mrigala. Indian J. Zootomy, v. 22, n. 3, p. 147-150, 1981.

RANZANI-PAIVA, M. J. T.; SILVA-SOUZA, A. Hematologia de peixes brasileiros. In: RANZANIPAIVA, M. J. T.; TAKEMOTO, R. M.; PEREZ LIZAMA, M. A. (Orgs.). Sanidade de organismos aquáticos. São Paulo: Varela, 2004. p. 89-120.

RANZANI-PAIVA, M. J. T.; RODRIGUES, E. L.; EIRAS, A. C.; VEIGA, M. L.; PACHECO, F. J. Alterações hematológicas em curimbatá, Prochilodus scrofa Steindachner, 1881, exposto ao Dipterex 500 (Trichlorfon). Bol. Inst. Pesca, v. 24, n. esp., p. 187-196, 1997.

RIVAS, L. R. Systematic review of the perciform fishies of the genus Centropomus. Copeia, n. 3, p.579-611, 1986.

ROSENFELD, G. Corante pancrômico para hematologia e citologia clínica: nova combinação dos componentes do May-Grünwald e do Giemsa num só corante de emprego rápido. Mem Inst Butantan, v. 20, p. 29-34, 1947.

SAAD, M. A. H.; EZZAT, A.; SHABANA, A. Effect of pollution on the blood characteristics of Tilapia zillii. Water, Air, Soil Pollut., v. 2, p. 171-179, 1973.

SARAVANAN, J. S.; HARIKRISHNAN, R. Effect of sublethal concentration of copper and endosulphan on haematological parameters of the freshwater fish, Sarotherodon mossambicus (Trewaves). J. Ecobiol., v. 11, p. 13-18, 1999.

SCHMIDT-NIELSEN, K. Fisiologia animal: adaptação e meio ambiente. 5.ed. São Paulo: Editora Santos, 2002. $611 \mathrm{p}$.

SERIANI, R.; RANZANI-PAIVA, M. J. T. Alterações hematológicas em peixes: Aspectos fisiopatológicos e aplicações em ecotoxicologia aquática. In: SILVASOUZA, A. T.; PEREZ LIZAMA, M. A.; TAKEMOTO, R. M. (Org.). Patologia e sanidade de organismos aquáticos. Maringá: ABRAPOA, 2012. p. p. 221-242 
SERIANI, R.; MOREIRA, L. B.; ABESSA，D. M. S.; MARANHO, L. A.; ABUJAMARA, L. D.; CARVALHO, N. S. B.; KIRSCHBAUM, A. A.; RANZANI-PAIVA, M. J. T. Hematological analysis in Micropogonias furnieri Desmarest, 1823, Scianidae, from two estuaries of Baixada Santista, São Paulo, Brazil. Braz. J. Oceanogr., v. 58, n. spec. 3, p. 87-92, 2010.

SERIANI, R.; DIAS, D. C.; SILVA, M. R. R.; VILLARES, E. O.; ABESSA, D. M. S.; MOREIRA, L. B.; RANZANI-PAIVA, M. J. T.; RIVERO, D. H. R. F. Hematological parameters of Oreochromis niloticus from a polluted site. Ann. World Aquacult. Soc. Available in:https://www.was.org/wasmeetings/meetings/ShowAbs tract.aspx?Id=17603. Accessed: 12/11/2012

SERIANI, R.; ABESSA, D. M. S.; KIRSCHBAUM, A. A.; PEREIRA, C. D. S.; ROMANO, P. \& RANZANIPAIVA, M. J. T. Relationship between water toxicity and hematological changes in Oreochromis niloticus. Braz. J. Aquat. Sci. Technol., v.15(2):47-53, 2011.

SERIANI, R.; PINNA, F. V.; SILVEIRA, F. L.; ROMANO, P.; ABESSA, D. M. S. Toxicidade de água e sedimentos e estrutura da comunidade bentônica do estuário do Rio Itanhaém, SP, Brasil resultados preliminares. O Mundo da Saúde, v. 30, p. 628-633, 2006.

SERIANI, R.; ABESSA, D. M. S.; MAGINI, C.; PINNA, F. V.; SILVEIRA, F. L.; ROMANO, P. Using bioassays and benthic community to evaluate the sediment quality at the estuary of Itanhaém River, SP, Brazil. O Mundo da Saúde, v. 32, p. 294-301, 2008.

SIQUEIRA, G. W.; BRAGA, E. S.; PEREIRA, S. F. P.; SILVA, E. Distribuição do mercúrio em sedimentos de fundo no Estuário de Santos SP/Brasil. Rem: Rev. Esc. Minas [Online], v. 58, n. 4, p. 308-316, 2005.

SOUSA, E. C. P. M.; ABESSA, D. M. S.; RACHID, B. R. F.; GASPARRO, M. R.; ZARONI, L. P. Ecotoxicological assessment of sediments from the port Santos and the disposal sites of dredged material. Braz. J. Oceanogr., v. 55, n. 2, p. 75-81, 2007.
VAN DER OOST, R.; BEYER, J.; VERMEULEN, N. P. E. Fish bioaccumulation and biomarkers in environmental risk assessment: a review. Environ. Toxicol. Pharmacol., v. 13, n. 2, p. 57-149, 2003.

VOS, J.; VAN LOVEREN, H.; WESTER, P.; VETHAAK, D., Toxic effects of environmental chemicals on the immune system. Trends Pharmacol. Sci., v. 10, p. 289$292,1989$.

WALKER, C. H.; HOPKIN, S. P.; SIBLY, R. M.; PEAKAL, D. B. Principles of ecotoxicology. London: Taylor \& Francis, 1996. $321 \mathrm{p}$

WEEKS, B. A.; ANDERSON, D. P.; DUFOUR, A. P.; FAIRBROTHER, A.; GOVEN, A. J.; LAHVIS, G. P.; PETERS, G. Immunological biomarkers to assess environmental stress. In: HUGGETT, R. J.; KIMERLY, R. A.; MEHRLE, P. M.; BERGMAN, H. L. (Eds.). Biomarkers: biochemical, physiological and histological markers of anthropogenic stress. Boca Raton: Lewis Publishers, 1992. p. 211-234. (SETAC special publications series).

WENDELAAR-BONGA, S. E. The stress response in fish. Physiol. Rev., v. 77, n. 3, p.591-625, 1997.

WINTROBE, M. M. Variations on the size and haemoglobin content of erythrocytes in the blood of various vertebrates. Folia Haematol., v. 51, p. 32-49, 1934.

ZUTSHI, B.; PRASAD, S. G. R.; NAGARAJA, R. Alteration in hematology of Labeo rohita under stress of pollution from Lakes of Bangalore, Karnataka, India. Environ. Monit. Assess., v. 168, p. 11-19, 2010.

(Manuscript received 05 January 2012; revised 15 October 2012; accepted 07 June 2013) 